\title{
A note on the potential role of philopatry and conspecific attraction as conservation tools in Audouin's Gull Larus audouinii
}

\author{
ALEJANDRO MARTÍNEZ-ABRAÍN, COVADONGA VIEDMA, NATALIA \\ RAMÓN and DANIEL ORO
}

\begin{abstract}
Summary
This short communication reports on the first record of Audouin's Gulls Larus audouinii breeding in captivity and on the behaviour of some individuals released as fledglings. During the period 1995-2000 a hand-reared male returned to its natal site and responded, year after year, to the translocation of a captive group of Audouin's Gulls for nesting site selection. The potential role of philopatry and conspecific attraction as conservation tools for this vulnerable seabird after an eight year experiment are discussed.
\end{abstract}

Many seabirds are known to be relatively philopatric, that is, they recruit mainly to their natal site (see for example Bradley and Wooller 1991). This phenomenon has been commonly exploited for conservation purposes for other bird taxa (e.g. raptors) through "hacking", the feeding of chicks within enclosures in the wild during the last stages of growth so that on their subsequent release they become imprinted to their fledging site (e.g. Sherrod et al. 1982). However, similar attempts for seabird species are very scarce (see Kress 1997 for an example with Atlantic Puffins Fratercula arctica and Leach's Storm Petrels Oceanodroma leucorhoa).

At a finer spatial scale, birds reaching their fledging grounds enter a decisionmaking process to assess the quality of the breeding site. Nesting site selection is a crucial process since it can affect most components of fitness (Danchin et al. 1998). Conspecifics seem to provide key clues about habitat suitability and quality that prospecting birds use to decide whether and where they will establish a breeding territory (Reed and Dobson 1993, Smith and Peacock 1990).

Audouin's Gull Larus audouinii is an endemic seabird of the Mediterranean region, classified as globally Near-threatened (BirdLife International 2000). As part of a conservation programme for the species, individuals have been kept in captivity at a recuperation centre in eastern Spain, some taken in as adults and some hand-reared as chicks. Here we report on the breeding behaviour of the captive gulls as well as that of individuals released as fledglings, in relation to the potential role of philopatry and conspecific attraction for the conservation and management of Audouin's Gull colonies.

In 1992, five eggs from the Columbretes archipelago colony $\left(39^{\circ} 51^{\prime} \mathrm{N} \mathrm{O}^{\circ} 4 \mathrm{O}^{\prime} \mathrm{E}\right)$ hatched at a recuperation centre (Centro de Protección y Estudio del Medio 
Natural) located at the Albufera de Valencia Nature Park. The chicks were handreared in captivity at the centre facilities (106 km south of the egg collection site), and subsequently released into the wild. All were ringed with darvic bands for individual field identification.

From 1995 to 2000 one of the released birds (a male determined by copulatory behaviour) was observed breeding at the centre accompanied by an unringed wild female ("wild pair" hereafter). A second captive-reared chick, released in 1995, was also observed at the recuperation centre three years after release, although it did not attempt to breed. There are no records of the other birds released in 1992. At the same time, a group of adult and subadult captive Audouin's Gulls (see Table 1) was experimentally translocated each year (see Figure 1) in order to monitor the response of the wild pair to the presence of captive conspecifics.

Within this group, a breeding pair of captive birds ("captive pair" hereafter) was formed during the study period, the year after the wild pair started breeding. This pair comprised the same two individuals each year. Reproductive parameters (laying date, clutch size, hatching success and productivity) of the wild and captive pairs were recorded by daily visits during the breeding season (March-July).

Laying dates did not show a consistent pattern throughout years between the two pairs (Table 1). Mean clutch size was similar for the wild and captive pairs (2.6 and 2.4 respectively) and although the average hatching success tended to be lower for the wild pair $(53 \%)$ than for the captive pair $(67 \%)$, significant differences were not detected (Fisher exact test combining data from all the years, $P=$ $0.312)$.

This is the first record of Audouin's Gull breeding in captivity and it indicates the potential to breed endangered gull species in captivity for conservation purposes. Our observations also confirm that occasionally Audouin's Gulls can breed close to human settlements (see Oro 1998 and references therein).

Fledging-site imprinting was probably responsible for bringing the handreared gulls back to their natal site year after year. However once there, nest site selection of the wild pair did not apparently occur at random nor was it based upon the nest site selected the previous year. On the contrary, this behaviour seemed to be strongly influenced by the presence of captive conspecifics, except in 2000 after predation by a dog the year before. Although the behaviour of the captive and wild pairs is not necessarily representative of the species, these facts point towards a crucial role of philopatry and especially conspecific attraction for colony persistence and growth in ground-nesting gulls (e.g. Oro and Pradel 2000). Thus, painted decoys and sound recordings could be promising conservation tools for Audouin's Gull population reinforcement, as they have been for several declining populations of other seabirds (Kress 1983, Kress 1997).

\section{Acknowledgements}

This study is the contribution no. 3 to the LIFE-NATURE program BA-3200/ 98/447 "Conservation of island SPAs in the Valencian region" financed by the Generalitat Valenciana and the EU. J. A. Gómez kindly provided historical data from the recuperation centre. A. Colomb made relevant suggestions for the struc- 


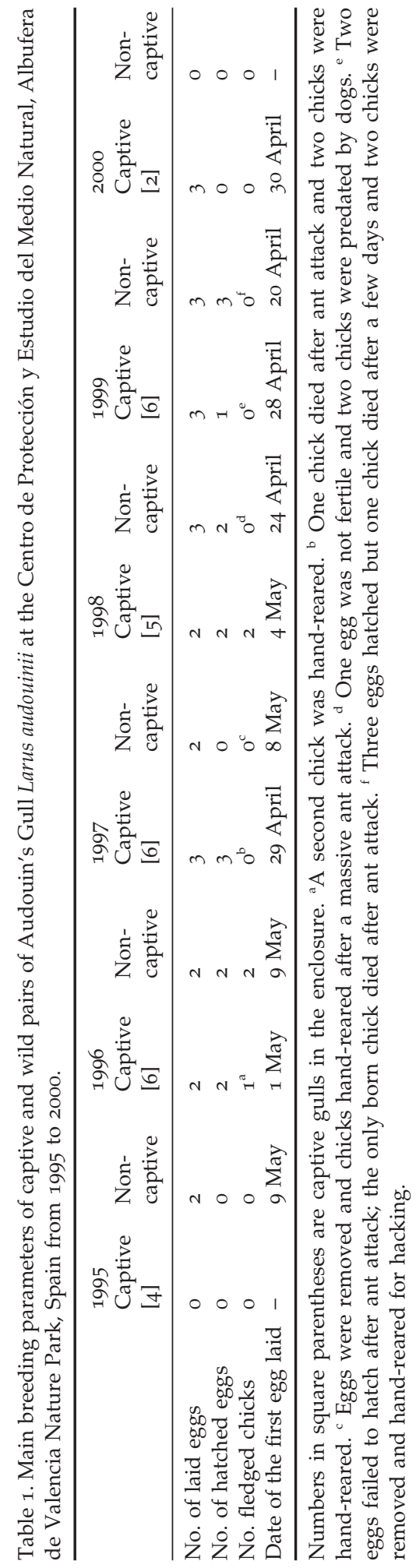



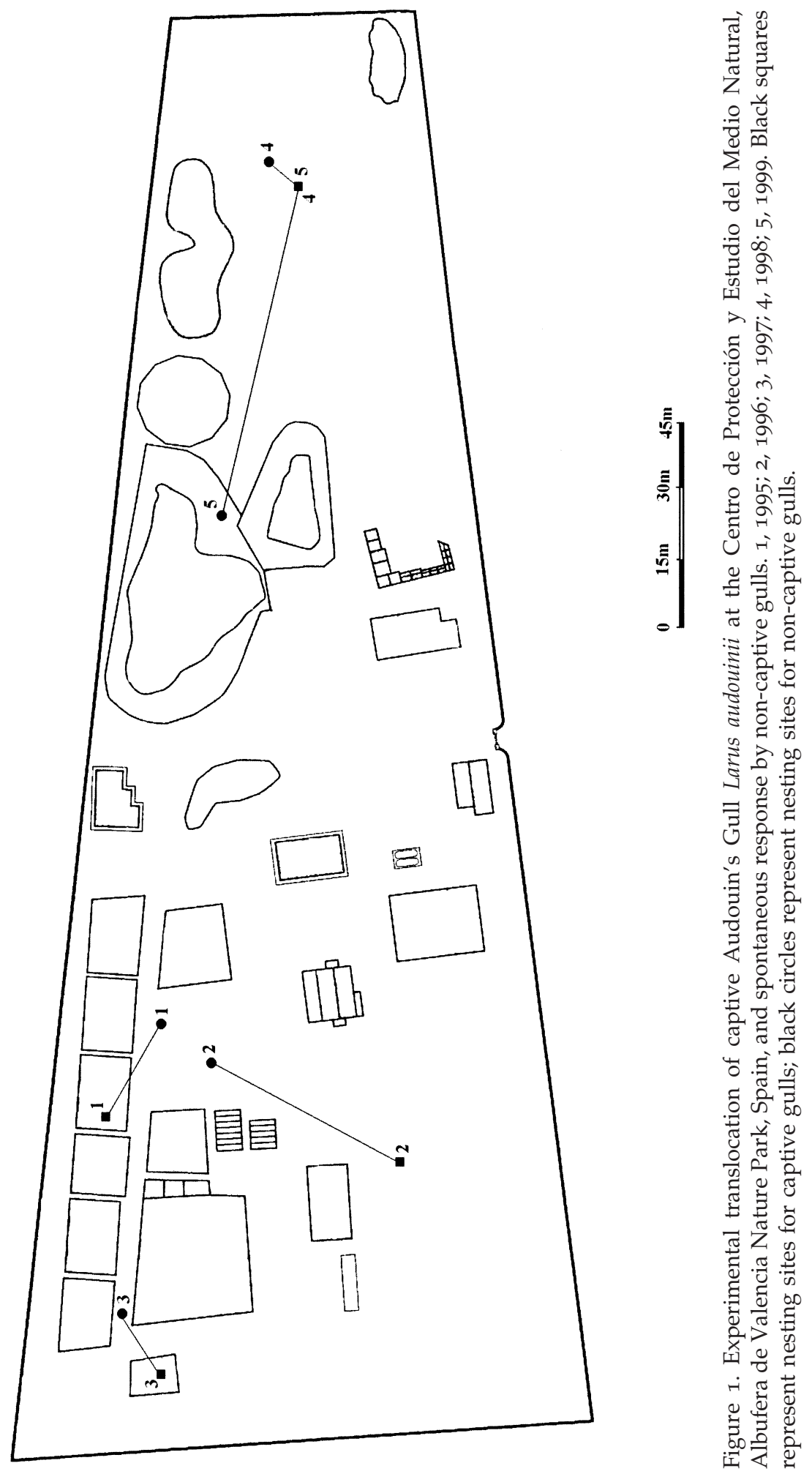
ture of the table. P. Prosper helped us designing a self-explanatory figure. The staff of the recuperation centre made this study possible. Our gratitude to all of them.

\section{References}

Birdlife International (2000) Threatened birds of the world. Cambridge, U.K.: Birdlife International.

Bradley, J.S. and Wooller, R. D. (1991) Philopatry and age of first-breeding in long-lived birds. Acta XX Congressus Internationalis Ornithologici: 1657-1665.

Danchin, E., Boulinier, T. and Massot, M. (1998) Conspecific reproductive success and breeding habitat selection: implications for the study of coloniality. Ecology 79: 24152428 .

Kress, S. W. (1983) The use of decoys, sound recordings, and gull control for reestablishing a tern colony in Maine. Col. Waterbirds 6: 185-196.

Kress, S. W. (1997) Using animal behavior for conservation: case studies in seabird restoration from the Maine Coast, USA. J. Yamashina Inst. Orn. 29: 1-26.

Oro, D. (1998) Audouin's Gull. Pp. 47-61 in M. A. Ogilvie, ed. The birds of the western Paleartic, 2. Oxford: Oxford University Press.

Oro, D. and Pradel, R. (2000) Determinants of local recruitment in a growing colony of Audouin's gull. J. Anim. Ecol. 69: 119-132.

Reed, J. M. and Dobson, A. P. (1993) Behavioural constraints and conservation biology: conspecific attraction and recruitment. Trends Ecol. Evol. 8: 253-256.

Sherrod, S. K., Heinrich, W. R., Burnham, W. A., Barclay, J. H. and Cade, T. J. (1982) Hacking: a method for releasing peregrine falcons and other birds of prey. Ithaca, NY: The Peregrine Fund.

Smith, A. T. and Peacock, M. M. (1990) Conspecific attraction and the determination of metapopulation colonization rates. Conserv. Biol. 4: 320-323.

ALEJANDRO MARTÍNEZ-ABRAÍN ${ }^{1}$ and DANIEL ORO

Instituto Mediterráneo de Estudios Avanzados (CSIC-UIB), Miquel Marqués 21, 07190 Esporles, Mallorca, Spain

COVADONGA VIEDMA and NATALIA RAMÓN

Centro de Protección y Estudio del Medio Natural, Conselleria de Medio Ambiente, Generalitat Valenciana, Avda. de los Pinares 106, 46012 El Saler, Valencia, Spain

${ }^{1}$ Author for correspondence; e-mail: jandroma@teleline.es

Received 11 September 2000; revision accepted 8 February 2001 
